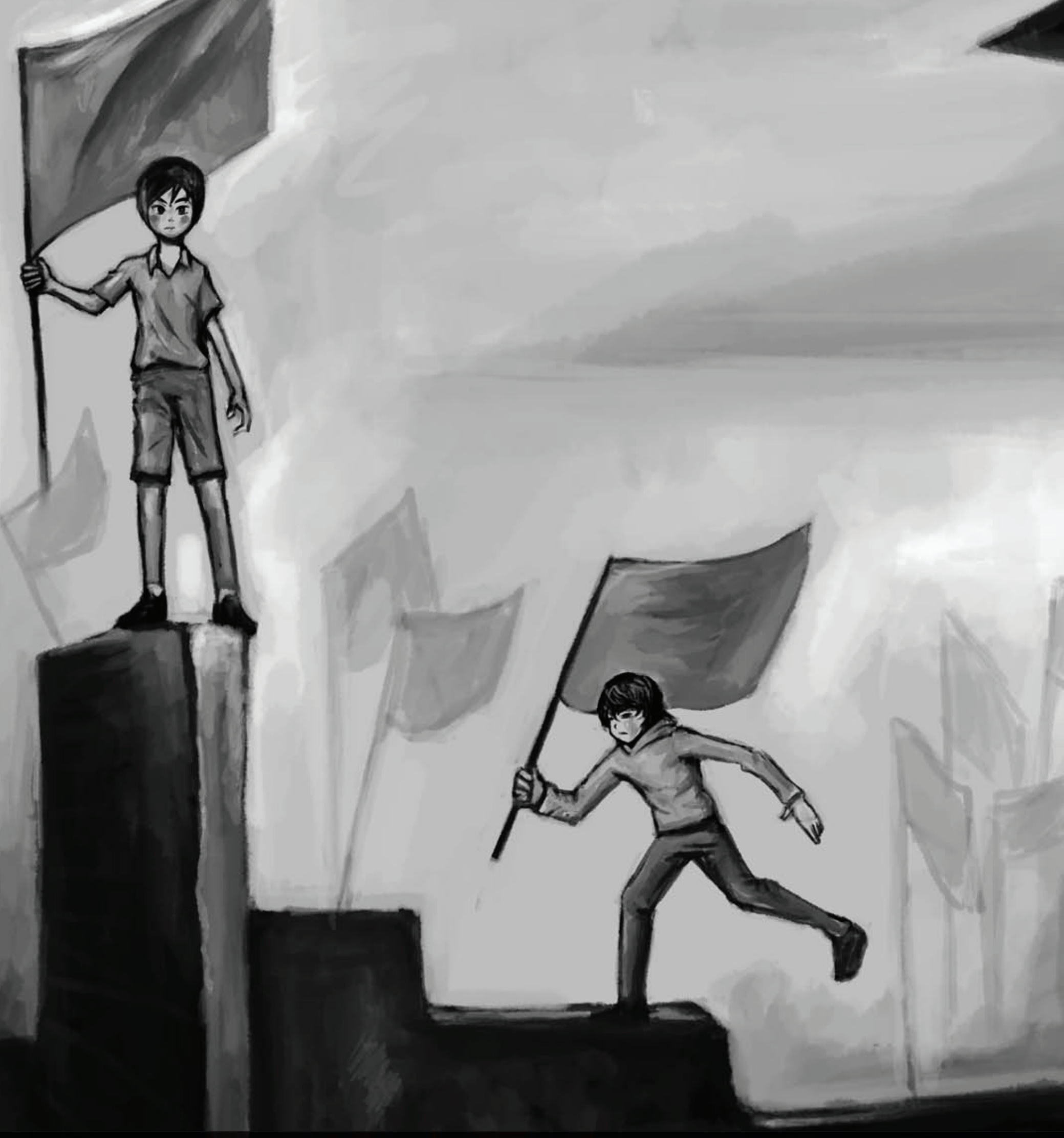

Has the Deliberative Model of Democracy an epistemic value? 



\title{
Has the deliberative model of democracy an epistemic value?
}

\author{
¿Tiene el modelo de democracia deliberativa \\ un valor epistémico? \\ 0 modelo de democracia deliberativa tem \\ valor epistêmico?
}

\section{Roberto García Alonso (España)}

Pontificia Universidad Javeriana

garcia.roberto@javeriana.edu.co

Roberto García Alonso es doctor en Ciencias Políticas y de la Administración por la Universidad Autónoma de Madrid. Es miembro y webmaster del Centro de Teoría Política de la UAM (CTP) y miembro del Grupo de Investigación de Teoría Política de la UAM. Actualmente se desempeña como profesor Asistente en el Departamento de Ciencia Política de la Pontificia Universidad Javeriana de Bogotá (Colombia).

\section{Resumen}

La democracia deliberativa es un ideal normativo de democracia. Este modelo no solo constituye una propuesta para la regeneración de la legitimidad de nuestras instituciones, sino también un mecanismo para la toma de decisiones. Se basa en dos dimensiones: una dimensión procesal de acuerdo con la cual el modelo exige la inclusión y una capacidad igual de influir en la decisión final de todos los afectados (Cohen, 1989; Bohman, 1996; Habermas, 1992...) y una dimensión sustantiva donde las decisiones políticas se toman a través de un procedimiento colectivo a través de la argumentación y el debate público. Si estas condiciones se respetan, las decisiones serán más racionales y mejores. Este artículo tiene dos objetivos. En primer lugar presentaré los elementos clave de esta concepción epistémica de la legitimidad política. En segundo lugar voy a mostrar los retos a los que se enfrenta. Por un lado, el carácter contrafáctico de muchos de sus propuestas y por el otro, los problemas obvios del evidente sesgo consensualistade este modelo.

\section{Abstract}

Deliberative democracy is a normative ideal of democracy. This model is a proposal for the regeneration of the legitimacy of our institutions, but also a mechanism for decision making. It is based on two different dimensions: a procedural dimension, where the model demands the inclusion and an equal capacity to influence the final decision of all those affected (Cohen, 1989; Bohman, 1996; Habermas, 1992 ...) and a substantive dimension where the political decisions are made through a collective procedure of argumentation and public discussion. If these conditions are recognized, the decisions will be more rational and better. This paper has two aims. First, I will present the key elements of this epistemic conception of political legitimacy. Secondly, I will show the challenges it faces. On the one hand,

\section{Resumo}

A democracia deliberativa é um ideal normativo de democracia. Este modelo não só constitui uma proposta para a regeneração da legitimidade das nossas instituições, mas também um mecanismo para a tomada de decisões. Baseia-se em duas dimensões: uma dimensão processual de acordo com a qual o modelo exige a inclusão e uma capacidade igual de influir na decisão final de todos os afetados (Cohen, 1989; Bohmam, 1996; Habermas, 1992...) e uma dimensão substantiva onde as decisões políticas tomam-se através de um procedimento coletivo através da argumentação e o debate público. Se estas condições se respeitam, as decisões serão mais racionais e melhores. Este artigo tem dos objetivos. Em primeiro lugar apresentarei os elementos chave de esta concepção epistêmica da legitimidade política. Em segundo lugar vou mostrar os retos 
the counterfactual of many of its postulates and on the other, the obvious problems of consensualist bias of this model

Palabras clave: Democracia deliberativa, el valor epistémico, el consenso, la racionalidad, la rectitud moral. aos que se enfrenta. Por um lado, o caráter contrafático de muitas das suas propostas e pelo outro, os problemas óbvios do evidente sesgo com consensualidade deste modelo.

Keywords: Deliberative democracy, epistemic value, consensus, rationality, moral rightness.

Palavras chave: Democracia deliberativa, o valor epistêmico, o consenso, a racionalidade, a retidão moral.

\section{Para citar este artículo / to cite this article / para citar este artigo:}

Garcia, Roberto (2012). Has the Deliberative Model of Democracy an epistemic value?. Panorama, VII (12), 23 - 37. 


\section{Introduction}

Most authors have defended that the deliberative democracy has an epistemic value. According to them, deliberation is a mechanism for the search of truth (Bohman, 1996: 6; Richardson, 2002: 76; Cfr. Habermas, 1992). However, this justification is plagued with problems.

Liberals defend a presumption in favor of individual liberty and limited liberty only to protect the equal rights of others. In this sense, they underline a priority of "just" above the considerations of "good life". Thisis essentially the liberal way of thinking about a just society. It denies the existence of anything that transcends individual preferences. Liberalism understands democracy as a formal and neutral procedure. According to it the legitimacy of the rules derives from the endorsement by the representatives in the Parliament following the established procedure. The justification of decisions can only be derived from adopting a procedure that ensures fairness and equity. From this perspective, the main objective of the policy will be the best compromise between private, opposite and irreconcilable interests, and explicitly refuses anything that transcends private preferences.

On the contrary, Jürgen Habermas claims that the moral agreementis possible. It is derived from a particular process of communication. A communication oriented to mutual understanding and this is subjected to several criteria for measuring the quality of dialogue ("Real Speech Situation”). The result of this process is a rational agreement, a rational consensus (Cfr. Habermas, 2000: 21). When we attribute epistemic value to this consensus, we assume that if this unanimous decision is the result of a deliberative process, it will be a sufficient condition to assert its moral rightness. If these conditions of measuring deliberation qualitywere recognized, the decisions would be correct from a moral point of view and they would be more rational and better.

.This work has two relevant dimensions. First, the plural character of our societies raises doubts about the real possibility of moral substantive agreement. Second, despite the resonance of Habermas's studies, the theoretical arguments have been presented without empirical evidence or a robust explanation. Both aspects will be addressed in this paper.

In this paper I will expose the weaknesses of the justification of deliberative democracy. First, I will describe the Habermasian deliberative model. Then, I will present the essential elements of this epistemic conception of democracy. This characterization is necessary in order to recognize the elements of this epistemic conception of democracy. Secondly, I will contrast their assumptions with the reality. In this sense, I will present some empirical evidences. These evidences will resolvedoubts about the benefits and the epistemic value of the deliberative model.

\section{The habermasian deliberative model}

Habermas's proposal is original in the following sense: the moral universalism of Habermas depends on a dialogical procedure of communication. This procedure is oriented to mutual understanding and this is subjected to several criteria for measuring the quality of dialogue ("Real Speech Situation"). According to this, this model is 
different from John Rawls'smonological model and the contemporary republican model - where the deliberation depends on virtuous participation of citizens, who are committed to the common good. This ideal deliberation allows us to reach a rational agreement.

Habermas resorted to an analysis of our communicative practices. In Theory of Communicative Action,Habermas supposes there is a close relation betweenrationality and knowledge, "who have knowledge, can be more or less rational". According to this, there are two types of actions, in accordance with the status of the rules that govern the behavior: we can find goal-directed actions we meet the rational action and teleological actionswithin. Communicative action is distinguished by Habermas from other forms of action. Communicative action is action based upon this deliberative process, where two or more individuals interact and coordinate their action agreed upon interpretations of the situation (Habermas, 1984: 86).

Habermas identifies and reconstructs a series of universal conditions or "universal validity claims" in the structures of argumentative speech. Within communicative action an agent must necessarily engage these claims and believe that such claims can be made.

The argument relies on the following assumptions:

(1) communication can proceed between two individuals only on the basis of a consensus regarding the validity claims raised by the speech acts they exchange;

(2) these validity claims concern at least three dimensions of validity: a) truthfulness, b) rightness, and c) truth.

(3) this mutual understanding is maintained on the basis of the shared presupposition that any validity claim agreed upon could be justified, if necessary, by having recourse to good reasons.

In other words, a speaker claims not only that what they say is true (c), but also that it is normatively right (b) and honest (a). Moreover, the speaker implicitly offers to justify these claims if they are challenged with reasons. The actions of the actors are not coordinated via egocentric calculations of interest, but they do lead to mutual understanding (Cfr. Habermas, 2001: 385).

This approach involves a "procedural view of rationality". Habermas situates rationality as aninherent capacity within language, especially in the form of argumentation. The validity of any norm may be subjected to this rational checkout, that is, this discursive procedure. In other words, rationality is a characteristic of the process by which the decision is made. "The intrinsic characteristics of the process allow for attributing a rational value to the decisions. The rationality inherent in this practice is seen in the fact that a communicatively achieved agreement must be ultimately based on reasons. And the rationality of those who participate in this communicative practice is determined by whether, if necessary, they could, under suitable circumstances, provide reasons for their expressions" (Habermas, 1984:17). 
He equated empirical truth with ideal justifiability - a consensus theory of truth-. According to that theory, the "truth condition of propositions is the potential assent of all others"; thus "the universal-pragmatic meaning of truth... is determined by the demand of reaching a rational consensus" (Habermas, 1971/2001: 86, 89). Such formulations suggest that Habermas equated the meaning of truth with the outcome of a universal, rational consensus, which he understood in reference to the ideal speech situation (Habermas, 1971/2001: 97-98).

In a moral dimension, Habermas translates this consensus theory of truth, thus, he summarizes his idealized conception of practical discourse in the "discourse principle": A rule of action or choice is justified, and thus valid, only if all those affected by the rule or choice could accept it in a reasonable discourse (Habermas, 1990: 66, 93).The Discourse principle thus applies moral rightness and ethical authenticity.

In other words, “ideal speech situation” acts as a regulative ideal. Habermas providing one set of criteria for measuring the quality of discourse refers to structural features: inclusiveness, equal communicative rights, the absence of repression or manipulation. Other criteria concern required dispositions of participants: reflexive attitudes towards one's own claims, willingness to take the demands and the counterarguments of the other seriously, and sincerity or the absence of manipulation and self deception (Habermas, 2005: 39-40). In this vein, for Habermas, the legitimacy of an authority only comes from a democratic process that allows a reasonable assumption for rational acceptance of their results (Habermas, 1992, 2005). The result of this procedure is the consensus, however, this does not mean the possibility of the persistence of deep ethical disagreement, like Rawls. For Habermas, the participants in a deliberation have to make a decision rationally motivated and it becomes from the same reasons" (Habermas, 1998: 161). In conclusion, the idea of legitimacy depends on the fulfillment of two essential conditions: 1) satisfying the procedural requirements for a correct procedure (formal legitimacy) and 2) the rational acceptability of the results of this procedure (substantive acceptability).

\section{An epistemic conception of democracy}

When we attribute epistemic value to this consensus, we assume that this unanimous decision is the result of a deliberative process. This means that:First, the existence of a correctness standard. This standard allows us to know when a decision is correct. In our case, this standard is the "ideal speech situation". According to Habermas this ideal situation operates like a criterion of decisioncorrectness. This "ideal situation" imposes regulatory conditions to the deliberative process (regulative ideal), the conditions of the process allow to attribute a rational value to the decisions. The legitimacy of decisions exclusively derived from these procedural conditions (Cfr. Perez Zafrilla, 2009, p. 158).

Secondly, there is a procedure: deliberation, that allows making those right decisions. According to the first point, this procedure should be subjected to these normative conditions that operate as a standard for assessing the quality of the dialogue. 
Thirdly and finally, the goal of these deliberative processes is the agreement among all participants. This agreement represents the right or the best decisions from the formal or procedural point of view but also it is the best from a substantive point of view.

In other words, Habermasian deliberative model is understood as a process that produces consensus. 1) The Habermasian deliberative model conceives the deliberation as a mechanism to discern the "rightness" of the rules of action, 2) It maintains a concept of consensus, particularly rigid because it requires a minimum agreement from the basis of the same substantive reasons resulting from the deliberative process itself; reasons are independent of the particular interpretations of good too. 3) It is possible because the process is subjected to strict procedural criteria, but also participants are subjected to the strict requirements of the communicative rationality (a reflexive attitude towards one's own beliefs and background assumptions, willingness to take the demands and the counterarguments of the other seriously, and sincerity or the absence if manipulation and self-deception.

\section{The assumptions of deliberation}

Liberal democracy involves a minimal sense of autonomy and equality. The main value in democracy is the basic political equality among all citizens, understood as a "prima facie" equal right to influence or determinate political decisions. The citizens are considered autonomous, they make their own choices and they have a basic and equal right to participation. All this constitutes democracy. This presupposes that none of us possesses an infallible epistemology. On the contrary, deliberative democracy represents an alternative point of view to this "pure proceduralist" conception of democracy and the "substantive" conceptions of democracy.

Deliberative democracy is an alternative ideal of political legitimacy. Ideally speaking, political decisions are considered legitimate if they are the product of a deliberative procedure of decision-making. The decisions, that are the result of a deliberation, are more legitimate because they have been adopted by procedural conditions that allow fair decisions. But, these decisions would not only be legitimate, but also they would be correct because they have been adopted on the basis of the best argument-of the rational argument. In this sense, the idea of epistemic value is the main source of moral validity of the deliberative model and the main argument in its defense.

In the deliberative democracy, political decisions are to be made through a collective procedure of argumentation where arguing consists in exchanging reasons, oriented to the goal of rationally convincing others, instead of strategic participation oriented to impose personal political preferences or desires on others (Manin, 1987, 352 and 353; Cohen, 1989, 17-21; Estlund, 1993; Gutmann and Thompson, 1996; Christiano, 1996, 53-55; Fishkin and Laslett 2003, 2); and it is supposed to lead us, at least ideally, to rational consensus.Deliberation assumes, as we have seen, both the existence of rightness (or impartiality, or some other equivalent) in political decisions, and the possibility to know which is the right (or impartial) decision (Cohen, 1986, Estlund, 1997: 174; Christiano, 1997).

In other words, when we attribute epistemic value to this procedure, this means that: 
First, it is the existence of a correctness standard. This standard allows us to know when a decision is correct. In our case, this standard is the "Real speech situation". According to Habermas, this ideal situation operates like a criterion of decision correctness. This "ideal situation" imposes regulatory conditions to the deliberative process (regulative ideal), the conditions of the process allow to attribute a rational value to the decisions.

Second, there is a procedure:deliberation, which allows getting those right decisions. According to the first point, this procedure should be subject to these normative conditions that operate as standard for assessing the quality of the dialogue.

The goal of these deliberative processes is the agreement among all participants. This agreement represents the right or the best decisions from the formal or procedural point of view but also it is the best from a substantive point of view. In other words, the legitimacy of decisions does not only derive exclusively from these procedural conditions. The idea of legitimacy depends on the fulfillment of two essential conditions: 1) satisfying the procedural requirements for a correct procedure (formal legitimacy) and 2) the rational acceptability of the results of this procedure (substantive acceptability).

In this sense, the deliberation could primarilybe defined as a qualified form of communication whose conditions under which it operates allows the beliefs, values and preferences of citizens to change and be more rational, thus allowing to find points in common.

It is possible because in all cases:

1) We assume "deliberative capacities" of the individuals. A successful deliberation depends on cognitive and moral capacities. Citizens who are able to have or create their own beliefs and preferences, with ability to consider alternatives and an attitude to receive favorable and serious demands and counter-arguments of others, etc., are required for deliberation. In other words, individuals are rational, ethical and moral agents. Individuals are explicitly assumed to have a basic cognitive capacity to argue with reasons, to recognize criteria of justification, to be logical and to reflect on their own presuppositions.

However, the research suggests that individual's capacities are less than assumed by deliberative democracy. Second, the use of the information and the formation of the individual judgments depend on contextual factors and important cognitive factors.

The empirical studies suggest that the individuals are not particularly rational and logical in their judgments. They show the important influence of cognitive factors in the formation of their judgments: the use of heuristic (Cfr. Downs 1957; Popkin, 1991; Sniderman, 1992), prejudices and stereotypes (Cfr. Miller, 1992) cognitive dissonance (Festinger, 1957) or pre-existing strong emotional commitments and preferences. Many studies have drawn attention to the powerful influence of cognitive factors: "cognitive victories", this invites us to consider important factors like the memory, the attention or remembering the arguments (CfrLupia 2002). 
Moreover, the information comes from our political environment (mass media, political parties...), but the final use depends on a complex interaction of factors like our "conscience", our values, knowledge, etc ... People do not have a full catalogue of opinions, people possess a number of considerations that may compete with each other, and their salience depends on the contextual framework (Cfr. Converse, 1964, Zaller, 1992).

2. It assumes a problematic presupposition regarding the nature of communication and group dynamics. The deliberation is presented as a communication normatively constrained, communication that aims to change the content of, intensity of, or reasons for the preferences, beliefs, actions or interpretations of one's interlocutors with respect to matters of public concern (Neblo, 2005: 174).

These conditions should ensure to reach agreement, a consensus among all participants. A consensus that, in the deliberative theory, appears as an expression of the rationality and the moral rightness.

In this light, deliberative democracy theory understands the communication as anessentially non-problematic phenomenon. Communication would not be more than a neutral vehicle for the transport of subjectively constructed views, a mere epiphenomenon resulting from the dynamic or cognitive structures of individuals and social structure. A minimal analysis of the latest research shows that communicative exchanges determine the quality of cognition. While the quality of the structures of communication are clearly affected by the cognitive abilities of the individuals involved, these cognitive abilities are themselves, at least in part a product of communicative exchanges in which individuals are regularly involved (Rosenberg 2002).

Moreover, the desirability of the deliberative process is derived from the real possibility of reaching a consensus. But obviously,any convergence of views cannot be regarded as relevant. Deliberative theory requires a qualified consensus, a rational agreement. This view has important implications, and suggests one question: how can we evaluate the consensus really reached?

The evaluation of consensus is a factual matter. We will only know the rational character of the real consensus if we examine the conditions under which consensus has been made. In this vein, then, the important thing is not the effective consensus, but the criteria of rationality introduced to qualify it.

Secondly, it is not sure that the consensus will be a necessary result of this communication process. The empirical studies about group processes challenge this idea. It is argued that we do not behave in the same way when we act individually than when we represent a group or we are part of one. There would be an important phenomenon as "discontinuity" or "groupthink". First, the concept of discontinuity refers to the idea that the existence of the group itself has a crucial impact on the behavior of individuals (Cfr. Ash, 1951, 1956). In this light the pressure on individuals and groups can induce that the individuals in a minority position would tend to accommodate their opinion to the opinion of the majority. Secondly, the tendency to unanimity among group members may be due to the groupthink phenomenon. This concept describes the tendency of individuals engaged in group process to change their preferences in the sense of the majority (Cfr. Janis 1972). Moreover, deliberation might transform preferences; democratic 
deliberation might help to accomplish this by allowing relevant constituencies to sort out and hopefully reduce the dimensions over which they disagree. But it is a real possibility that, it might even exacerbate conflict. This might occur in at least two ways. First, disagreement and conflict are not only the starting point of deliberation but a primary creative resource. As a creative process, however, deliberation might well proliferate rather than diminish understandings of what is at stake in a given political contest. Secondly, even if deliberation does induce a shared understanding of the dimensions of conflict, this may serve simply to focus attention on the depth of disagreement. A participant may conclude that "if this is what is at stake, then I really disagree (Knight y Johson, 1994: 286; Cfr. Sunstein, 2002)1.

The real problem is that deliberative democracy presupposes that consensus is possible and preferable to conflict. The consensus represents a more rational and better decision and the real possibility of moral agreement. The use of public and rational discussion as a mechanism of deactivation of the conflict and differences in the field of ethical and political reflections. However, conflict and consensus are two sides of the same coin, are two dimensions of political phenomena. In deliberative theory the relationship between conflict and consensus means that there is a sequence where the conflict is the starting point and the consensus is the point of arrival. However, the interrelationship between conflict and consensus is much more complex. The possibility of consensus does not eliminate the possibility of conflict in general, because this is an intrinsic dimension of the concept of politics. Moreover, the consensus is not necessarily desirable, because it might be oppressive, "nullify the symbolic dimension of the game between authority and opposition” (Maldonado, 2007: 46, Cfr. Shapiro, 2002: 199; Mouffe, 1993).

The consensus is not a necessary result of the deliberative process. It is possible that the individual or group of individuals, exercising their personal autonomy, refuse to accept the consensus and thus become dissident. This dissent should constitute the basis of legitimacy. According to Muguerza, it would be a lower limit to the consensus, when according to our consciousness we determine that the collective decision violates my human condition" (1990: 682) "imperative of dissent" or "alternative of dissent".

This tension between the universality of consensus and individual autonomy and the possibility that the deliberative process does not necessarily culminate in anagreement are powerful reasons. We need to consider the possibility of reasonable disagreement and dissent as possible results of the deliberative process and we need to think of alternatives to consensus as the key to the legitimacy of political decisions.

\section{Conclusions}

In this paper, I have attempted to offer an understanding of the epistemic value of the democratic deliberation. First we saw that deliberative democracy is not only a model of legitimacy of political decisions but also a decision-making mechanism. In this vein, the attribution of epistemic value to the deliberation means that decisions reached under this model were better and more rational. According to Habermas the legitimacy of an authority only comes from a democratic process that allows a reasonable assumption for rational acceptance of their results

1 Here the crucial point is the "force of the better argument". Other forms of influence are explicitly excluded, so that interlocutors are free to be convinced with reasons. 
(Habermas, 1992, 2005). The result of this procedure is the consensus; this does mean the possibility of the solution of deep ethical disagreement. For Habermas, the participants in a deliberation have to get a decision rationally motivated and it becomes from the same reasons" (Habermas, 1998: 161). In other words, he defends a rigid concept of consensus which has an epistemic value and represents the best and more rational decision.

Secondly, we provided an overview of the constituent elements of the epistemic justification of deliberative democracy. In this light, we have seen as the success of deliberation depends on the important assumptions about the deliberative capacities of citizens, the nature of communication processes and group dynamics. Finally,I have examined some empirical studies which suggest that the deliberative assumptions regarding the cognitive capacities of individualsare incorrect and that communication is more than just a neutral medium or vehicle. Moreover, I have shown that the consensus is not a necessary result of the deliberation procedure, and it is possible that the deliberation exacerbated conflict or created a false consensus. This suggests that we need to think of alternatives to consensus as the key to the legitimacy of political decisions.

It is true that that deliberative democracy is a counterfactual model and a regulative ideal. But the real problem is that deliberation is usually treated as a decision-making procedure with important cognitive and political benefits. However, this approach falls short to appreciate the consequences of the deliberative process. The role of empirical evidences in theories of deliberation should not be counted as evidence for or against deliberation, but it can show the various dimensions of success and the means of achieving them. A satisfactory answer to this question should entail measures to enhance the democratic capacity of citizens and the group dynamics in different participatory practices within the public sphere.

Unless the capacity gained within these practices is visibly and comprehensibly linked to actual decisionmaking processes, this model will only be a vain aspiration. 


\section{References}

1. Ash, S. E(1951) "Effects of Group Pressure on the Modification and Distorsion of Judgments" En Steere, $\mathrm{H}$ (ed.) Groups, Leadership and Men. Pittburgh: Carnegie.

2. Bohman, J. (1996). Public Deliberation. Pluralism, Complexity, and Democracy,

3. Cambridge: MIT Press.

4. Cohen, J. (1986) An Epistemic Conception of Democracy, Ethics, 97 (1), 26-38.

5. Cohen, J. (1989) The Economic Basis of Deliberative Democracy, Social Philosophy and Policy, 6, (2): 25-50.

6. Converse, P. (1964)."The Nature of the Beliefs Systems in Mass Publics." En Apter D. Ideology and Discontent, New York: Free Press

7. Christiano, T. (1996) The Rule of the Many. Colorado: Westview Press.

8. Christiano, T. (1997) "The Significance of Public Deliberation”. En Bohman, J. \&Regh, W. Deliberative Democracy: Essays on Reason and Politics. Cambridge: MIT Press.

9. Downs, A. (1957) An economic theory of democracy. Nueva York: Harper and Row.

10. Estlund, D (1993) “Who's Afraid of Deliberative Democracy? The Strategic/Deliberative Dichotomy in Recent Constitutional Jurisprudence," Texas Law Review: 1437-1477.

11. Estlund, D (1997) "Beyond Fairness and Deliberation: The Epistemic Dimension of Democratic Authority," En Bohman, J y Regh, W (1997) Deliberative Democracy, MIT Press,

12. Fishkin, J. \&Laslett, R. (2003) Debating Deliberative Democracy. Oxford: Blackwell.

13. Gutmann, A. \& Thompson, D. (1996) Democracy and Disagreement. Cambridge: Harvard University Press.

14. Habermas, J (1984) Theory of Communicative Action: Reason and the Rationalization of Society. Boston, BeaconPress.

15. - (1992) "Tres modelos de democracia sobre el concepto de una política deliberativa", Debats, 39: 18-21.

16. — (1998). Facticidad y validez, Madrid: Trotta.

17. - (2000) Aclaraciones a la Ética del Discurso, Madrid: Trotta 
18. - (2001) Teoría de la Acción Comunicativa: Complementos y Estudios Previos. Madrid: Cátedra.

19. - (2005) "Concluding Comments on Empirical Approaches to Deliberative Politics", ActaPolítica, 40: 384-392.

20. Janis, I. (1972) Victims of Groupthink. Boston: Houghton Mifflin.

21. Knight, J. y Johnson.J (1994). «Aggregation and deliberation: On the possibility

22. of democratic legitimacy", Political Theory, 22, 2: 277-296.

23. Lupia, A (2002) Deliberation disconnected: What it takes to improve civic competence. En Law and Contemporary Problems. 65, 3: 133-150.

24. Manin, B. (1987). "On legitimacy and political deliberation," Political Theory,15(3): 338-368.

25. Maldonado, M.A (2007) "La política en la teoría deliberativa. Notas sobre deliberación, decisión y conflicto". Revista Española de CienciaPolítica, 16: 37-59.

26. Miller, D. (1992) "Deliberative Democracy and Social Choice, Political Studies, XL, Special Issue: 54-67.

27. Mouffe, Ch. (1993). The return of the political.Londres: Verso.

28. Muguerza, J (1989) "La alternativa del disenso.(En torno a la fundamentación ética de los derechos humanos)En Muguerza, J et al. El fundamento de los derechos humanos, edición preparada por Gregorio Peces Barba Martinez. Madrid: Debate.

29. - (1990). Desde la perplejidad (Ensayos sobre la ética, la razón y el diálogo).Madrid: Fondo de Cultura Económica

30. Neblo, M.A. (2005) "Thinking through Democracy: Between the Theory and Practice of Deliberative Politics", ActaPolitica, 40: 169-181.

31. Perez Zafrilla, P.J. (2009) "Democracia deliberativa: una apuesta por el valor epistémico de la deliberación pública". Revista de Filosofía, 34, 1: 155-173

32. Popkin. S. L. (1991).The Reasoning Voter: Communication and Persuasion in Presidential Campaigns. Chicago: University of Chicago Press.

33. Richardson, H. (2002). Democratic autonomy, Public reasoning about the ends of policy, Oxford, Oxford University Press.

34. Rosenberg, S.W. (2002). The Not So Common Sense: Differences in the Way People Judge Social and Political Life. New Haven: Yale University Press. 
35. - (2005). "The Empirical Study of Deliberative Democracy: Setting a Research Agenda", ActaPolítica40: 212-224.

36. Shapiro, I. ( 2002). «Optimal Deliberation?», en J. Fishkin y P. Laslett, eds., Debating deliberative democracy, Journal of Political Philosophy, special number 10,2: 196-211.

37. Sniderman, P. M., Brody, R.A. y Tetlock P. et al. (1991). Reasoning and choice.Explorations in political psychology. Cambridge: Cambridge University Press,

38. Sunstein, C (2002). «The law of group polarization». En The Journal of Political Philosophy, special number, 10, 2: 175-195

39. Vallespin, F (2001) "Teoría del discurso y acción comunicativa en JürgenHabermas." En Máiz, R (ed.) Teorías Políticas Contemporáneas. Valencia: Tirant lo Blanch.

40. Wilson, R.W. (1992). Compliance Ideologies: Rethinking Political Culture. New York: Cambridge University Press.

41. Zaller, J. R. (1992). The Nature and Origins of Mass Opinion.Cambridge: Cambridge UniversityPress. 